\title{
Socio-Economic Drivers of Degradation and Their Implication on Conservation of River Lumi Riparian Ecosystem in Kenya
}

\author{
Leila A. Ndalilo1,2*, Bernard K. Kirui ${ }^{1}$, Elias K. Maranga1 \\ ${ }^{1}$ Department of Natural Resources, Egerton University, Egerton, Kenya \\ ${ }^{2}$ Coast Eco-Region Research Programme, Kenya Forestry Research Institute, Malindi, Kenya \\ Email: ${ }^{*}$ leylilo@yahoo.com
}

How to cite this paper: Ndalilo, L. A., Kirui, B. K., \& Maranga, E. K. (2020). Socio-Economic Drivers of Degradation and Their Implication on Conservation of River Lumi Riparian Ecosystem in Kenya. Open Journal of Forestry, 10, 307-319. https://doi.org/10.4236/ojf.2020.103020

Received: March 11, 2020

Accepted: June 1, 2020

Published: June 4, 2020

Copyright $\odot 2020$ by author(s) and Scientific Research Publishing Inc. This work is licensed under the Creative Commons Attribution International License (CC BY 4.0).

http://creativecommons.org/licenses/by/4.0/

\begin{abstract}
Riparian forests ecosystems play significant role in biodiversity conservation and provision of ecosystem goods and services which support local livelihoods. However, riparian ecosystems are threatened by degradation attributed to anthropogenic activities. Understanding the interaction between anthropogenic activities and socio-economic factors, and their associated impact on riparian degradation is essential for designing appropriate management strategies for these ecosystems. This study assessed the socio-economic factors that drive degradation and their implication on conservation of River Lumi riparian ecosystem. Semi-structured questionnaires, Focus Group Discussion (FGDs) and key informant interviews were used to collect the data. The findings indicate that crop farming and livestock production were the main sources of livelihood practiced by $84 \%$ and $70 \%$ of the households respectively. Consequently, agricultural intensification resulting from increased demand for agricultural commodities (33\%), over-grazing coupled with influx of livestock from private ranches and neighbouring pastoralist Maasai community (20\%), and deforestation fuelled by population increase (17\%) were the main drivers of degradation in River Lumi riparian ecosystem. The findings indicate that about $91 \%$ of the adjacent communities are dependent on River Lumi for their sustenance and their livelihoods will be affected by continued degradation of the riparian ecosystem; thus there is need for development of appropriate management strategies including sustainable livelihood systems to conserve River Lumi riparian ecosystem.
\end{abstract}

\section{Keywords}

River Lumi, Riparian Ecosystem, Socio-Economic, Degradation and Conservation 


\section{Introduction}

Riparian forest ecosystems contribute significantly to food security, livelihoods and national economies through direct exploitation of fisheries, water for irrigation, provision of wood materials and hydropower generation (Kafumbata et al., 2014; IPBES, 2018). In addition, these forests are important areas of global biodiversity and are regarded as biodiversity hotspots. They provide ecosystem services including regulation of water and soil quality, and minimize the impacts of landscape disturbance on stream ecosystems (Rodriguez et al., 2011). People also derive both direct and indirect benefits from riparian ecosystems (Wang et al., 2014). However, despite their immense importance, riparian forests are threatened by prevailing high rate of deforestation and degradation attributed to socio-economic factors (Rodriguez et al., 2011). In developing countries, the conversion of watersheds into agricultural land and urban areas has resulted in disruption of ecosystem integrity and deterioration of ecosystem services, which is the aggregate of ecosystem goods and services that represent the benefits human populations derive directly or indirectly from ecosystem functions (Wang et al., 2014). The growing populations and mismanagement of complex, fragile and poorly understood riparian forest ecosystems continue to jeopardize the livelihoods of local populations as well as the prospects for environmental protection and rehabilitation (World Bank, 1992; Foley et al., 2011). Thus, the protection and management of riparian forest ecosystems has emerged as both a local and national policy imperative throughout the developing countries (Faye, 2016).

In Kenya, degradation of riparian forests is on the increase and has largely been attributed to anthropogenic activities resulting from human population growth and increasing poverty levels leading to overexploitation of resources (Monene, 2017). Studies indicate that population growth-induced agricultural intensification, and conversion of forests to agriculture and grassland are the main threats to the forests respectively (Ngigi et al., 2007; Maitima et al., 2010; Mango et al., 2011). In River Lumi basin, there is a growing concern of riparian degradation resulting from deforestation and conversion of large tracts of land for irrigated agriculture (Muli, 2014; Ngugi et al., 2015). There is evidence from several studies (NEMA, 2009; Muli, 2014; Ngugi et al., 2015) that the area around River Lumi has experienced rapid and extensive land use changes over the past couple of years in response to socio-economic drivers. This is despite the immense importance of River Lumi which is the main source of clean water to the entire Taveta sub-county, supports farming activities in the area as well as biodiversity conservation and also contributes significantly to food supplies along the Kenyan Coast.

Evidence has shown that different ecosystems experience different drivers of degradation depending on the prevailing socio-economic factors. Knowledge on the interaction between anthropogenic activities and socio-economic factors, and their associated impact on riparian forest degradation is a prerequisite for designing appropriate management strategies for conservation of River Lumi ri- 
parian ecosystem. The aim of this study was to identify the socio-economic factors that drive degradation and their implication on conservation of River Lumi riparian ecosystem.

\section{Materials and Methods}

\subsection{Study Area}

The study was undertaken in River Lumi riparian ecosystem, which forms part of Lake Jipe watershed in Taita Taveta County, Kenya. River Lumi is $71 \mathrm{~km}$ long, and originates from Mt. Kilimanjaro flowing North-East wards to cross the border from Tanzania to Kenya eventually flowing into Lake Jipe, a transboundary lake between Kenya and Tanzania. The riparian area covers an area of about 590 $\mathrm{km}^{2}, 75 \%$ of which is in Kenya (Ngugi et al., 2015), and is situated in the volcanic foothills zone with underground water and springs emanating from Mt. Kilimanjaro (Ngugi et al., 2015). The altitude of the area ranges from 1200 m.a.s.l in the lowlands to 1800 m.a.s.l in the highlands. The area experiences a dry semi-arid climate with a bi-modal rainfall pattern. The annual rainfall range between $300 \mathrm{~mm}$ to $1200 \mathrm{~mm}$ with a mean annual rainfall of $616 \mathrm{~mm}$. Temperatures are fairly constant with a mean monthly maximum of approximately $32^{\circ} \mathrm{C}$ and mean monthly minimum of $17^{\circ} \mathrm{C}$ (Republic of Kenya, 2014) (See Figure $1)$.

\subsection{Sampling Technique}

River Lumi riparian ecosystem was defined as the interface between land and the river including the riverine forest adjacent to the river. The riparian ecosystem was stratified in three main administrative locations namely Njukini, Chala and Mboghoni which are situated in the upper, middle and lower sections of River Lumi respectively. The strata are characterized by different socio-economic activities and land uses which impact differently on riparian conservation; Njukini is dominated by livestock production, while Chala and Mboghoni are dominated by mixed farming and crop farming respectively. This provided a comparative basis of evaluating the effect of the various socio-economic activities on conservation of River Lumi riparian ecosystem. Systematic sampling was used to select households living up to $5 \mathrm{~km}$ from River Lumi, in the three locations proportionate to the total number of households in each location. This was achieved by allocating unique codes to households in each location and picking every $5^{\text {th }}$ household until the required number of households was attained (Table 1).

The formula for sample size determination was

$$
n_{f}=\frac{n}{1+\frac{n}{N}}
$$

where $n_{f}$ is desired sample size when population is less than $10,000, n$ is the desired sample size and $N$ is the estimated population of the three locations. 


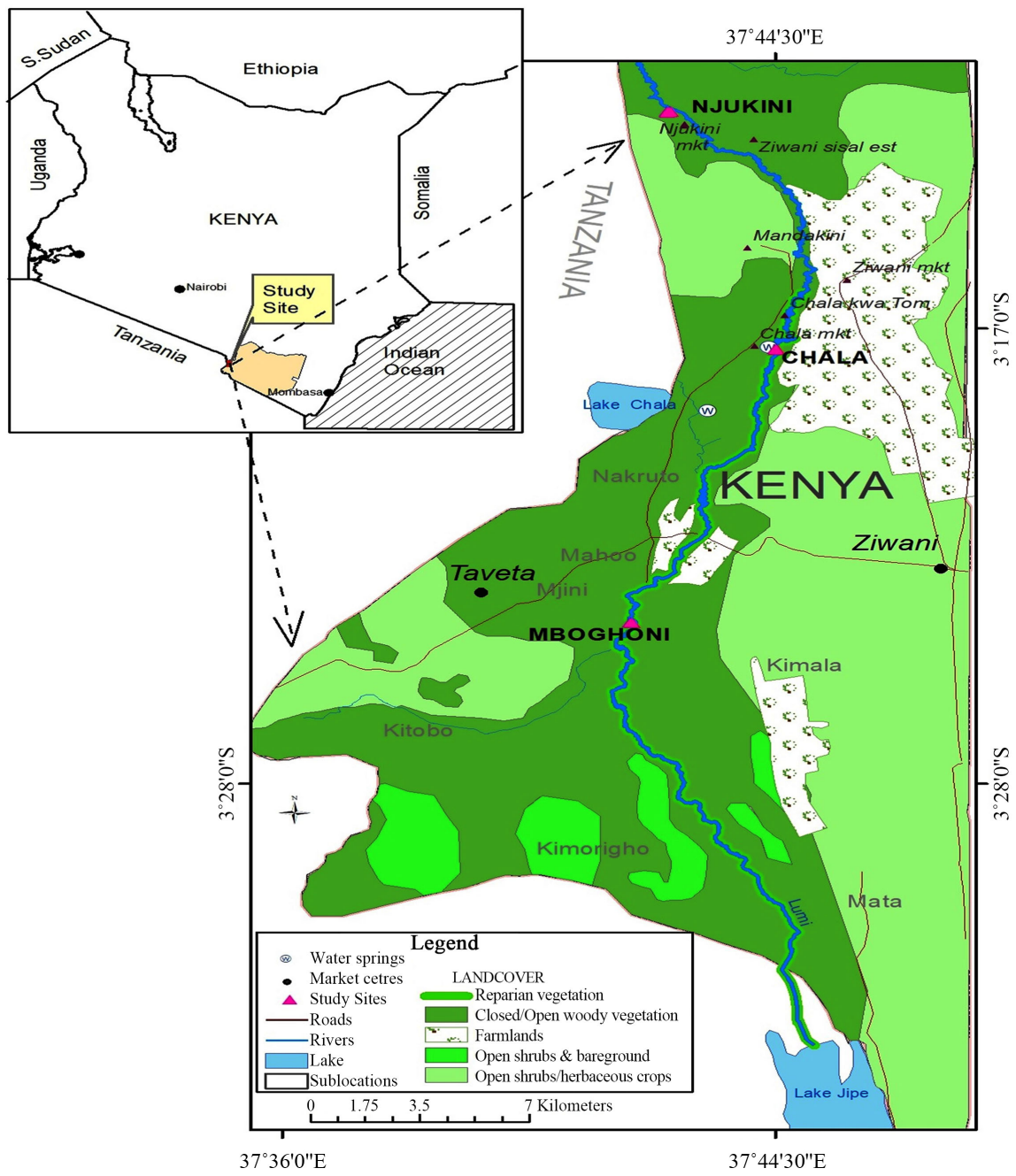

Figure 1. Location of the study area (Source, KEFRI GIS Department).

Table 1. Sample size of households by location.

\begin{tabular}{ccc}
\hline Location & Total household number & Sample size $\left(\boldsymbol{n}_{f}\right)$ \\
\hline Njukini & 2295 & 184 \\
Chala & 1325 & 105 \\
Mboghoni & 790 & 64 \\
Total & $\mathbf{4 4 1 0}$ & 353 \\
\hline
\end{tabular}

$$
n_{f}=\frac{384}{1+\frac{384}{4410}}=353
$$

A pilot survey was undertaken prior to the data collection exercise to pretest household questionnaires. A total of 35 questionnaires comprising $10 \%$ of the sample projected for the larger parent study were administered to selected households in order to enhance reliability and validity of the results. 


\subsection{Data Collection Methods}

Semi-structured questionnaires were administered through oral interviews with selected households living in Njukini, Chala and Mboghoni locations. The key themes covered by the questionnaire were land ownership and use, livelihood activities and their impact on catchment degradation, water resource governance and management system and community participation in conservation activities. The main drivers of degradation in River Lumi riparian ecosystem were also assessed. One Focus Group Discussion (FGDs) was held in each of the three locations along River Lumi in order to record community perceptions on historical drivers of degradation and their implication on conservation of River Lumi riparian ecosystem. Key informant interviews with representatives from relevant government departments, Non-governmental Organizations (NGOs) and Community Based Organizations (CBOs) were also conducted to provide insights on the effect of socio-economic factors on the riparian ecosystem. Secondary data on changes in population, area under crop and livestock production and market prices were obtained from relevant government offices including Ministry of Agriculture and livestock production and Kenya National Bureau of Statistics.

\subsection{Data Analysis}

Data collected were entered into Statistical Package for Social Science (SPSS) version 23.0 and coding done. The variables entered were analyzed to obtain descriptive statistics which were presented in the form of frequency Tables, charts and graphs. Analysis of Variance was used to test significant differences in means of variables and least significant differences in means were separated using Tukey's post hoc test with a 5\% probability significance threshold.

\section{Results}

\subsection{Demographic Profiles of Households}

The average households size comprised of 5 members $(5.14 \pm 0.21)$, while the gender distribution of household heads showed that $57.2 \%(n=202)$ were male while $42.8 \%$ ( $n=151)$ were female. Majority $(33.3 \%)$ of the household heads had no formal education, $23.3 \%$ had primary education, $23.0 \%$ had secondary education while only $20.4 \%$ had at least tertiary education. The average size of land per household was 2.9 hectares $(2.9 \pm 0.25)$. Site specific household profiles are outlined in Table 2.

Majority (95\%) of the households were permanent residents with only $5 \%$ being immigrants. Land was owned individually by $67 \%$ of the households, $28 \%$ of the households owned land communally while 5\% owned land through leasehold. Analysis of the ethnic composition of the three locations revealed that they are inhabited by different ethnic groups with varying socio-economic activities; Njukini location is mainly inhabited by the Maasai community who are pastoralists, Chala by the Kamba community who are both crop farmers and livestock keepers, and Mboghoni by the Taveta community who are mainly crop farmers. 
Table 2. Demographic profiles of households $(n=353)$.

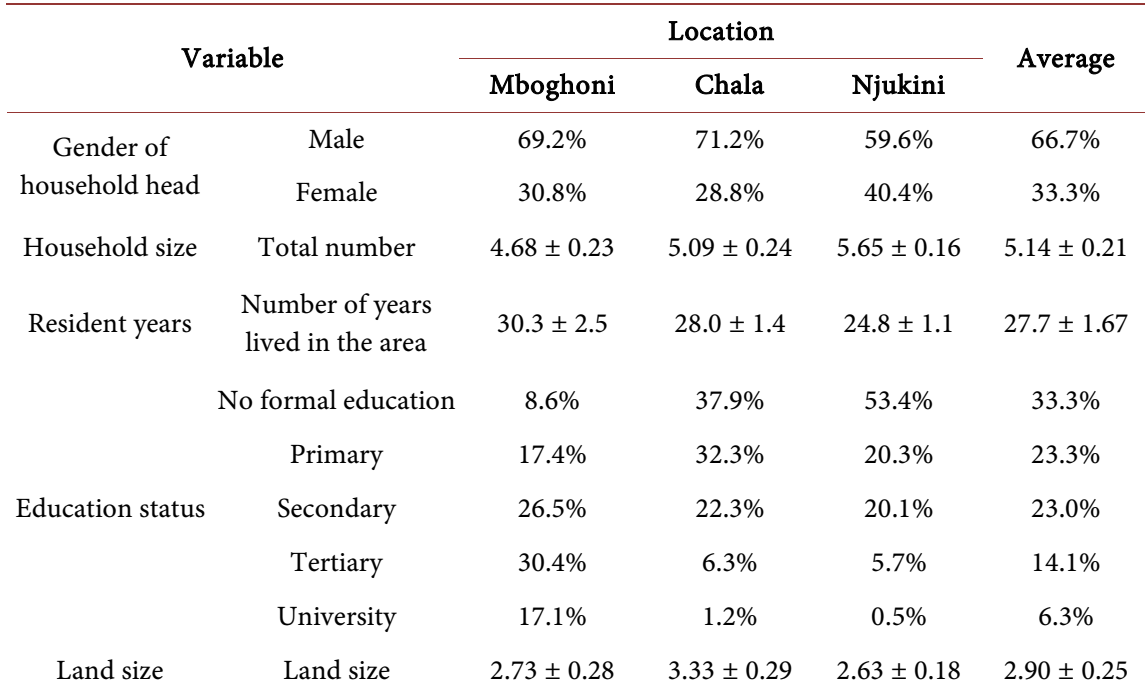

These livelihood activities have different implications on conservation of the riparian ecosystem. About $91 \%$ of households living in the three locations were dependent on River Lumi, highlighting the significance of the river and its riparian ecosystem in sustaining local livelihoods.

\subsection{Socio-Economic Drivers and Implication on Conservation of River Lumi Riparian Ecosystem}

\subsubsection{Main Livelihood Sources}

The main sources of livelihood among households living adjacent to River Lumi riparian ecosystem were farming and livestock keeping which were practiced by $84 \%$ and $70 \%$ of the households, respectively. The main crops grown were maize, bananas, tomatoes, onions, leafy vegetables, green grams and beans, while the main livestock kept were cattle, goats and sheep. Both crop farming and livestock production were mainly done for commercial purposes with the surplus produce used for subsistence. Respondents mentioned that the area under crop production has increased tremendously in a period of seven years between 2011 and 2018 from an average of about 1.5 to 2.5 ha per household. The increase in area under crop production was attributed to the need to diversify crops grown in order to avert effects of climate change, increased demand for agricultural products in main towns in the Coast region such as Voi, Mombasa and Malindi, and competitive market prices for agricultural products. The findings revealed that although the numbers of livestock kept by households living adjacent to River Lumi have declined over time, there was an influx of livestock from private ranches and neighbouring pastoralist communities.

\subsubsection{Household Sources of Income}

Crop farming was the leading source of income among households living adjacent to River Lumi riparian ecosystem, followed by small scale businesses, livestock production and casual work (Figure 2). 


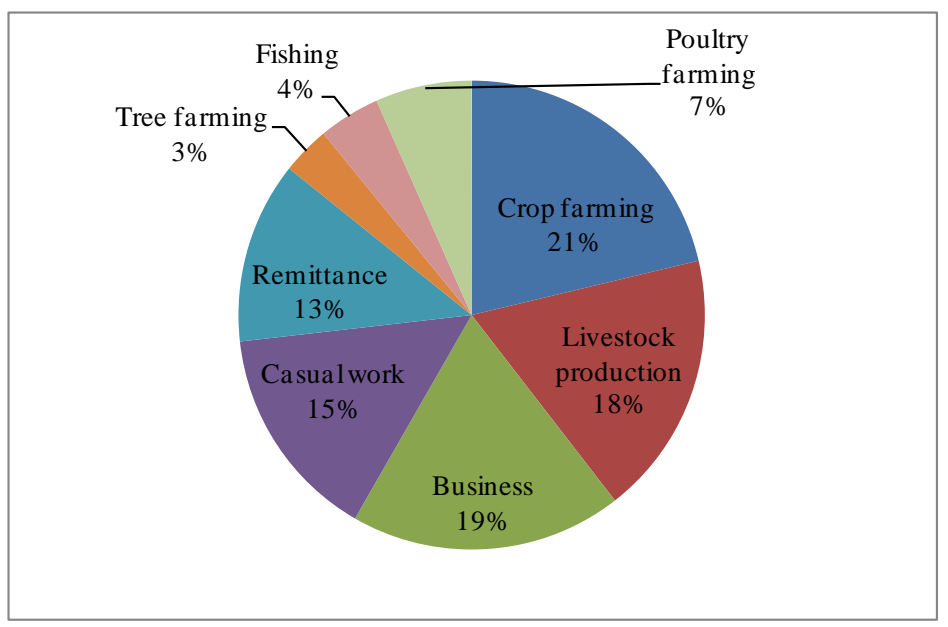

Figure 2. Household sources of income

Small scale businesses contributed significant amounts of income to households since the study area is located near Taveta, a Kenyan-Tanzanian border town which is a major trading corridor. Notably, Njukini which is predominantly a livestock keeping area generated higher income from crop farming than livestock production since most of the livestock kept in the location are owned by pastoralist communities who live in the neighbouring Loitoktok area in Kajiado County but are watered at River Lumi. Quarrying was practiced by only a few households living in Njukini and Chala but generated a lot of income due to the high demand for construction materials in the nearby urban centres. Tree farming was mainly practiced in Chala and Mboghoni and contributed the least to household income due to the low number of households engaged in it as an economic activity (Table 3 ).

\subsubsection{Community Perceived Threats to River Lumi Riparian Ecosystem}

The main threats to conservation of River Lumi riparian ecosystem were mentioned as deforestation (34\%), crop farming (33\%), overgrazing (20\%), weak management by Water Resource Management Authority (WRMA) (6\%), inadequate community participation in riparian conservation (4\%) and population increase (3\%) (Figure 3).

An analysis of the perception of the respondents on the human population dynamics along the riparian ecosystem revealed that the population of communities living adjacent to River Lumi had increased significantly in a period of 10 years between 2009 and 2019. In Taveta Sub-County, the population increased by $34.8 \%$ from 67,665 in 2009 to 91,222 in 2019 (KNBS, 2019). This was said to have increased exploitation pressure and impacted negatively on conservation of the riparian ecosystem as noted by $86 \%$ of the households. The negative impacts of increased human population were listed as: deforestation for charcoal production and human settlement (38\%); over-extraction of water for irrigation and domestic use (37\%); pollution of the river by agrochemicals (8.1\%) and over-grazing of the riparian vegetation (5\%). 
Table 3. Main household sources of income in the study locations.

\begin{tabular}{ccccc}
\hline \multirow{2}{*}{ Source of income } & \multicolumn{2}{c}{ Location, Income (KES per annum) } & \multirow{2}{*}{$\begin{array}{c}\text { Average HH income } \\
\text { (KES per annum) }\end{array}$} \\
\cline { 2 - 4 } & Njukini & Chala & Mboghoni & 170183.27 \\
Crop farming & 210000.00 & 146000.00 & 154549.80 & 146291.13 \\
Livestock production & 180000.00 & 38000.00 & 220873.40 & 150255.57 \\
Business & 152000.00 & 96000.00 & 202766.70 & 119333.33 \\
Casual work & 20000.00 & 258000.00 & 80000.00 & 100666.67 \\
Remittance & 60000.00 & 132000.00 & 110000.00 & 26666.67 \\
Tree farming & - & 50000.00 & 30000.00 & 300,000 \\
Quarrying & 540000.00 & 360000.00 & - & 34,000 \\
Fishing & - & 62,000 & 40000.00 & 53333.33 \\
\hline
\end{tabular}

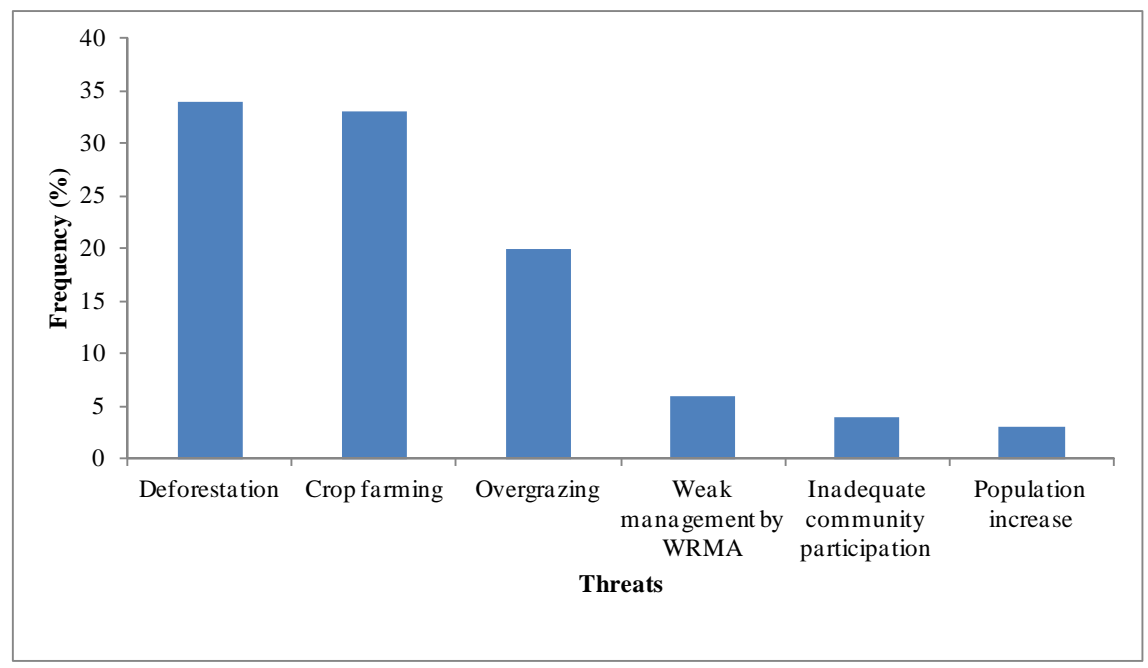

Figure 3. Threats to River Lumi riparian ecosystem.

\subsection{Management of Threats}

The local communities outlined a number of measures that should be put in place in order to manage the identified threats. These included strict enforcement of laws and regulations governing riparian protection (38\%), afforestation and reforestation (21\%), community sensitization on existing rules and regulations as well as importance of riparian conservation (13\%), appropriate livestock stocking levels (8\%) and fencing of the riparian area to deter destructive human activities (3\%). Discussions with key informants further revealed that there are existing opportunities which could be leveraged to mitigate the existing threats and conserve River Lumi riparian area and the adjacent riparian forest. These include availability of appropriate technologies developed by research organizations on forest restoration which can be applied to ensure successful restoration of the degraded riparian forest, increased awareness of local communities on the importance of environmental conservation which could stimulate community 
participation in conservation, concerted efforts of diverse stakeholders in sensitizing communities for increased conservation awareness, good will from the County Government of Taita Taveta which has department of environment and natural resources to spearhead and promote conservation of the riparian ecosystem and existing networks and partnerships amongst government agencies, Non-governmental Organizations, Community Based Organizations and Community Forest Associations which are important for successful restoration activities.

\section{Discussion}

The socio-economic characteristics of households are likely to influence use of River Lumi and the adjacent riparian forest. For instance, the average household size determines the amount of products extracted by households from the riparian forest while the size of land per household determines the type of land use, which in turn has implication on conservation of the riparian forest. In River Lumi riparian ecosystem, the relatively small sizes of land which stood at an average of 2.9 hectares per household was a major contributing factor to encroachment of riparian ecosystem including the riparian forest in a bid to expand agricultural activities amidst a growing population. The education levels of households were generally low with only $20.4 \%$ of the household heads having attained post-secondary education. Education is a proxy variable for livelihood improvement and plays an important role in poverty reduction. Poverty has a direct relationship with the level of dependence on natural resources with poor people being over-reliant on natural resources for their survival (Chambers \& Conway, 1991). Poverty has implications on utilization and management of the riparian ecosystem, and was in fact mentioned as a major driver of over-extraction of forest products particularly charcoal and timber which are traded locally. Land tenure also has implications on resource management with insecure land tenure being a major cause of unsustainable resource utilization. According to Kindu et al. (2015), land tenure regimes are important drivers of land use change, and communal land ownership has been identified as a major contributor to the destruction and over-exploitation of natural resources (Chidumayo, 2002). Secure tenure right is thus a prerequisite to sustainable management of River Lumi riparian ecosystem.

Crop farming and livestock production were the main livelihood activities undertaken by households living adjacent to River Lumi. The two livelihood activities were almost entirely dependent on River Lumi and the adjacent riparian ecosystem through crop irrigation and livestock grazing. Key informant interviews revealed that the area under crop farming has increased tremendously while there is an increase in number of livestock coming into water in River Lu$\mathrm{mi}$ from the neighbouring pastoralist communities and private ranches thus exerting pressure on the riparian ecosystem. Expansion of the area under crops and influx of livestock have had significant negative impacts on the riparian 
ecosystem leading to reduction in water flow, increased sedimentation and eutrophication, reduced riverine vegetation, reduced tree diversity and high seasonality of the river. The results of this study compares well with findings of Ryan et al. (2003) which found that agriculture has tremendous impact on the riparian zone mainly through increased sediment and chemical loading, encroachment and over-grazing. The increasing area under crop production was attributed to the growing demand for agricultural crops and competitive commodity prices. According to Coxhead and Shively (2005), the rapid integration of watershed economies with the national economies in which they exist is one of the factors contributing to agricultural expansion along riparian areas. Nzunda et al. (2013) further argue that expansion of cultivation along riparian areas has been fueled by growing demand for agricultural products that are important for improving food security and generating income.

Deforestation, crop farming, overgrazing, weak and uncoordinated management of the riparian ecosystem by Water Resource Management Authority (WRMA) and other stakeholders, inadequate community participation in riparian conservation, and population increase were highlighted as the main threats to conservation of River Lumi riparian ecosystem. Moreover, the significance of crop farming as a leading source of household income is likely to fuel both agricultural intensification and expansion in a bid to maximize the income generated, with negative implications on the riparian ecosystem and particularly the riverine forest. The presence of quarrying as a major income generator further exerts pressure on the riparian ecosystem and is likely to contribute to land degradation. This is further exacerbated by the low level of tree planting among households which is an indicator of over-dependence on the riparian forest for fuel wood, construction materials and other tree products with likely negative impacts on the riparian ecosystem. These factors are likely to contribute to the degradation of the natural resource base which supports the livelihoods of local communities. According to Kalaba et al. (2010), and Mayaux et al. (2013), the livelihoods of rural people are highly dependent on natural resources thus alterations of ecosystem services due to changes in land use and land cover negatively affect the ability of biophysical systems to support human needs.

Deforestation was attributed to increased demand for tree products resulting from population increase. Moreover there is poor enforcement of rules and regulations governing protection and conservation of riparian ecosystems by WRMA. This was further exacerbated by poor coordination amongst the various stakeholders including government departments, NGOs, CBOs and local communities who are engaged in various conservation measures. Inadequate community participation affected the sustainability of conservation initiatives in River Lumi riparian ecosystem and was attributed to inadequate incentives to encourage community participation in conservation activities. Population increase resulted to increased demand for forest and agricultural products resulting to deforestation and agricultural expansion respectively. These findings compares well with 
those of Ngugi et al. (2015) which indicated that the main cause of riparian forest degradation is a combination of ignorance, economic exploitation, poor farming practices and over-exploitation of forest products. The community recommended strict enforcement of laws and regulations governing riparian protection, afforestation and reforestation, community sensitization, appropriate livestock stocking levels and fencing of the riparian area in order to mitigate the existing threats.

\section{Conclusion}

River Lumi riparian ecosystem provides an important livelihood support system for adjacent local communities who depend on it for their livelihoods. The main economic activities dependant on the riparian ecosystem are crop farming and livestock production. These economic activities continue to impact negatively on the ecosystem mainly through over-abstraction of water for irrigation, pollution from agrochemicals, deforestation and over-grazing hence leading to land degradation. Moreover the existence of cases of communal land ownership coupled with small landholdings poses a threat to conservation of the riparian forest and the entire riparian ecosystem due to agricultural intensification, encroachment of riparian area and unsustainable farming practices. The low levels of tree planting among households and quarrying present additional threats for conservation of River Lumi riparian ecosystem. Population increase coupled with weak management of the riparian ecosystem by Water Resource Management Authority and other relevant stakeholders, and inadequate community participation in conservation initiatives present additional threats to the conservation of River Lumi riparian ecosystem. This calls for a participatory process in the development of appropriate management strategies for conservation of River Lumi riparian ecosystem.

\section{Recommendations}

The findings indicate that the livelihoods of households living adjacent to River Lumi riparian ecosystem will be affected by continued degradation of the riparian ecosystem. There is a need for coordinated management of the riparian ecosystem bringing on board all relevant stakeholders including government agencies, NGOs, CBOs, private companies and local communities. There is also need for monitoring and frequent patrols, as well as enforcement of rules and regulations governing riparian conservation. Furthermore, the local communities should be sensitized on appropriate conservation measures in order to reduce the impact of human activities on riparian forest degradation. Measures should also be taken to develop a payment for ecosystem service scheme to provide incentives for community participation in conservation activities. An integrated development and conservation approach encompassing provision of sustainable livelihood options should also be employed to ensure sustainable management of River Lumi riparian ecosystem. 


\section{Acknowledgements}

The authors acknowledge the financial and logistical support from Kenya Forestry Research Institute and RUFORUM through the TagDev Programme of Egerton University. The assistance of Kenya Forest Service staff, the enumerators, local administration, local community and other key informants for willingly providing useful information during the study is highly appreciated.

\section{Conflicts of Interest}

The authors declare no conflicts of interest regarding the publication of this paper.

\section{References}

Chambers, R., \& Conway, G. (1991). Sustainable Rural Livelihoods: Practical Concepts for the 21 st Century (29 p.). IDS Discussion Paper 296, London: IDS.

Chidumayo, E. N. (2002). Changes in Miombo Woodland Structure under Different Land Tenure and Use Systems in Central Zambia. Journal of Biogeography, 29, 1619-1626. https://doi.org/10.1046/j.1365-2699.2002.00794.x

Coxhead, I., \& Shively, G. (2005). Economic Development and Watershed Degradation. Wallingford: CAB International.

Faye, L. C. (2016). Impacts of Community-Forest Management on Land Use Change, Vegetation Dynamics and Carbon Stocks in South-Eastern Senegal. Ph.D. Thesis, Kumasi: Kwame Nkrumah University of Science and Technology.

Foley, J. A., Ramankutty, N., \& Brauman, K. (2011). Solutions for a Cultivated Planet. Nature, 478, 337-342. https://doi.org/10.1038/nature10452

IPBES (2018). Summary for Policymakers of the Assessment Report on Land Degradation and Restoration of the Intergovernmental Science-Policy Platform on Biodiversity and Ecosystem Services. Bonn: Intergovernmental Science-Policy Platform on Biodiversity and Ecosystem Services.

Kafumbata, D., Jamu, D., \& Chiotha, S. (2014). Riparian Ecosystem Resilience and Livelihood Strategies under Test: Lessons from Lake Chilwa in Malawi and Other Lakes in Africa. Philosophical Transactions of the Royal Society Biological Sciences, 369, Article ID: 20130052. https://doi.org/10.1098/rstb.2013.0052

Kalaba, F. K., Chirwa, P. W., Syampungani, S., \& Ajayi, O. C. (2010). Contribution of Agroforestry to Biodiversity and Livelihoods Improvement in Rural Communities of Southern African Regions. In T. Tscharntke, C. Leuschner, E. Veldkamp, H. Faust, E. Guhardja, \& A. Bidin (Eds.), Tropical Rainforests and Agroforests under Global Change (pp. 461-476). Berlin: Springer. https://doi.org/10.1007/978-3-642-00493-3_22

Kindu, M., Schneider, T., Teketay, D., \& Knoke, T. (2015). Drivers of Land Use/Land Cover Changes in Munessa-Shashemene Landscape of the South-Central Highlands of Ethiopia. Environmental Monitoring Assessment, 187, 452. https://doi.org/10.1007/s10661-015-4671-7

KNBS (2019). 2019 Kenya Population and Housing Census. Volume III: Distribution of Population by Age and Sex. Kenya National Bureau of Statistics https://www.knbs.or.ke/?wpdmpro=2019-kenya-population-and-housing-census-volu me-iii-distribution-of-population-by-age-sex-and-administrative-units

Maitima, J. M., Olson, J. M., Mugatha, S. M., Mugisha, S., \& Mutie, T. (2010). Land Use Changes, Impacts and Options for Sustaining Productivity and Livelihoods in the Basin 
of Lake Victoria. Journal of Sustainable Development in Africa, 12, 3-11.

Mango, L. M., Melesse, A. M., McClain, M. E., Gann, D., \& Setegn, S. G. (2011). Land Use and Climate Change Impacts on the Hydrology of the Upper Mara River Basin, Kenya: Results of a Modeling Study to Support Better Resource Management. Hydrological Earth Systems Science, 15, 2245-2258. https://doi.org/10.5194/hess-15-2245-2011

Mayaux, P., Pekel, J. F., Desclée, B., Donnay, F., Lupi, A., Achard, F., \& Nasi, R. (2013). State and Evolution of the African Rainforests between 1990 and 2010. Philosophical Transactions of the Royal Society B. Biological Sciences, 368, 2012-2030. https://doi.org/10.1098/rstb.2012.0300

Monene, A. K. (2017). Effects of Watershed Land Use Change on Streamflow of Motoine/Ngong River, Nairobi River Basin, Kenya. Mathematics and Physical Sciences Research, 5, 113-120.

Muli, J. M. (2014). The Impact of Irrigated Agriculture in Dry Lands on the Natural Environment: A Case Study of Chala Ward in Taita Taveta County, Kenya. M.Sc. Thesis, Nairobi: University of Nairobi.

NEMA (2009). Lake Jipe Basin Integrated Management Plan 2009-2014. National Environment Management Authority

Ngigi, S. N., Savenije, H. G., \& Gichuki, F. N. (2007). Land Use Changes and Hydrological Impacts Related to Up-Scaling of Rainwater Harvesting and Management in Upper Ewaso Ng'iro River Basin, Kenya. Land Use Policy, 24, 129-140. https://doi.org/10.1016/j.landusepol.2005.10.002

Ngugi, K., Ogindo, H., \& Ertsen, M. (2015). Impact of Land Use Change on Hydrology of Mt. Kilimanjaro: The Case of Lake Jipe Catchment. Geographical Research Abstracts, 17, 2015-4526.

Nzunda, N. G., Munishi, P. P. T., Soka, G. E., \& Monjare, J. F. (2013). Influence of Socio-Economic Factors on Land Use and Vegetation Cover Change in and around Kagoma Forest Reserve in Tanzania. Ethiopian Journal of Environmental Studies and Management, 6, 480-488. https://doi.org/10.4314/ejesm.v6i5.5

Republic of Kenya (2014). Taita Taveta County Integrated Development Plan. Nairobi: Government Printers.

Rodriguez, L. C., Pascual, U., Muradian, R., Pazmino, N., \& Whitten, S. (2011). Towards a Unified Scheme for Environmental and Social Protection: Learning from PES and CCT Experiences in Developing Countries. Ecological Economics, 70, 2163-2174. https://doi.org/10.1016/j.ecolecon.2011.06.019

Ryan, R. L., Erickson, D. L., \& De Young, R. (2003). Farmers' Motivations for Adopting Conservation Practices along Riparian Zones in Mid-Western Agricultural Watershed. Journal of Environmental Planning and Management, 46, 19-37. https://doi.org/10.1080/713676702

Wang, S., Wu, B., \& Yang, P. (2014). Assessing the Changes in Land Use and Ecosystem Services in an Oasis Agricultural Region of Yanqi Basin, Northwest China. Environmental Monitoring Assessment, 186, 8343-8357.

https://doi.org/10.1007/s10661-014-4009-x

World Bank (1992). World Development Report 1992: Development and the Environment. Washington DC: The World Bank. https://doi.org/10.2307/1973669 